\title{
PENGARUH CITRA MEREK DAN KUALITAS INFORMASI TERHADAP MINAT KONSUMEN BERBELANJA KEMBALI DI ZALORA
}

\author{
Ni Luh Mega Widiani, Ni Luh Putu Indiani, Ni Made Wahyuni \\ Fakultas Ekonomi dan Bisnis Universitas Warmadewa \\ indi_arca@yahoo.com
}

\begin{abstract}
ABSTRAK
Aktivitas berbelanja online saat ini sangat digemari oleh masyarakat karena situs jual beli online menawarkan produk yang menarik minat konsumen dan memberikan kemudahan saat berbelanja. Zalora merupakan toko online yang diminati oleh masyarakat, dibuktikan dengan raihan top brand index tertinggi selama beberapa tahun berturut-turut. Penelitian ini bertujuan untuk menganalisis faktor-faktor yang mempengaruhi minat konsumen berbelanja di Zalora. Penelitian ini dilakukan di kota Denpasar. Populasi dalam penelitian ini adalah masyarakat di Denpasar yang pernah berbelanja di situs Zalora dalam waktu 1 tahun terakhir. Sampel yang diambil sebanyak 112 responden. Pengumpulan data mempergunakan metode survey dengan instrumen kuesioner. Teknis analisis data menggunakan analisis regresi linier berganda. Hasil penelitian menemukan bahwa citra merek dan kualitas informasi berpengaruh positif dan signifikan terhadap minat beli online. Untuk meningkatkan Citra Merek, hal-hal yang dapat dilakukan Zalora adalah memberikan diskon secara frekuentif, menampilkan informasi produk secara detail termasuk foto dengan resolusi tinggi dan memastikan bahwa Zalora memberikan manfaat dan nilai bagi konsumen. Untuk meningkatkan Kualitas Informasi, hal-hal yang dapat dilakukan oleh Zalora adalah memastikan bahwa informasi produk disajikan secara akurat dan lengkap, menyajikan informasi produk dalam format yang mudah dipahami, dan mengirimkan notifikasi secara tepat waktu mengenai status pesanan.

Kata kunci: Citra merek, kualitas informasi, minat beli online.
\end{abstract}

\begin{abstract}
Online shopping activity is currently very popular in the societyas online shops offer attractive products and provide convenience when shopping. Zalora is a highly preferred online shop, as it achieved the highest top brand index for several. This study aimed to analyze factors that influence consumer intentionto shop at Zalora. This research was conducted in Denpasar. The population in this study are consumers in Denpasar who have shopped at Zalora in the past 1 year. Samples were 112 respondents. Data collection used survey method with questionnaire as instrument. Data was analyzed using multiple linear regression analysis. The results showed that brand image and information quality has a positive and significant impact on online purchase intention. To improve Brand Image, Zalora needs to provide frequent discounts, display detailed product information including high-resolution photos and ensure that it provides benefit and value to consumers. To improve the information quality, Zalora needs to ensure that product information is presented accurately and completely, present product information in an easily understood format, and send timely notifications about the order status.

Keywords: Brand image, information quality, online purchase intention.
\end{abstract}




\section{PENDAHULUAN}

Era digitalisasi saat ini ditandai dengan perkembangan teknologi dan informasi yang begitu pesat, sehingga menghasilkan peluang bisnis baru yang semakin beragam khususnya memanfaatkan media online. Perkembangan media online tidak hanya dimanfaatkan dalam pengelolaan informasi semata, namun telah mampu menghasilkan pundi-pundi mata pencaharian bagi masyarakat khususnya dalam melakukan penawaran produk. Dengan adanya media online sebagai media transaksi online di era saat ini, dapat memupuk jiwa kreatifitas dan inovasi masyarakat dalam memanfaatkan peluang bisnis yang sangat potensial. Adyanto dan Suryono (2018) menyatakan bahwa perkembangan bisnis online di Indonesia sangat cepat dan penuh inovasi teknologi seiring dengan semakin banyaknya pengguna teknologi.

Berkembangnya teknologi dan informasi, menyebabkan semakin banyaknya tokoonlinebermunculan di berbagai kalangan, mulai dari remaja hingga orang dewasa. Berkembang pesatnya toko online mengubah pola belanja konsumen yang dulunya bersifat konvensional menjadi modern melalui toko online (Anggraeni \& Mediawati, 2016). Dari sekian banyak toko online di Indonesia, Zalora adalah toko online yang banyak diminati oleh masyarakat. Zalora merupakan anak perusahaan dari situs belanja online di Eropa yaitu Zalando. Zalora menjual berbagai merek terkenal yang ada di Indonesia. Zalora memiliki website yang menarik sehingga konsumen tidak merasa bosan dan Zalora menampilkan berbagai informasi yang relevan. Ketika konsumen membuka situs website zalora.co.id, konsumen dapat dengan mudah mengakses produk yang ditawarkan dan semua informasi lengkap tentang produk. Zalora menjual produk fashion dengan berbagai jenis pilihan. Produk yang ditawarkan Zalora sangat bervariasi dengan brand-brand ternama kelas lokal, nasional, dan internasional yang telah dikenal oleh masyarakat dengan kualitas produk yang terjamin.

Zalora memang terbukti sebagai toko online yang memiliki citra kuat di masyarakat. Hal ini didukung hasil survey terhadap konsumen Indonesia. Terdapat 5 besar toko online di Indonesia yaitu Zalora, Lazada, Berrybenka, Shopee dan Tokopedia. Toko fashion online yang menduduki peringkat pertama top brand award mulai dari tahun 2015-2018 menurut survey Indonesia adalah Zalora (Topbrand, 2019). Dengan persentase top brand index award dari tahun 2015 sebesar $54.7 \%$, 2016 sebesar $40.5 \%$, 2017 sebesar 40.1\% dan 2018 15.5\%, Zalora telah berhasil melakukan strategi bisnis atau strategi pemasaran yang baik. Dibalik keberhasilannya tersebut, Zalora terus berupaya dalam menawarkan produk-produk yang berkualitas dengan harga dan pelayanan yang sesuai sehingga konsumen dapat tetap setia berbelanja di Zalora. Hal ini menimbulkan ketertarikan untuk menganalisis faktor-faktor yang mempengaruhi minat konsumen berbelanja di Zalora.

Menurut Kotler dan Armstrong (2003) minat beli konsumen adalah perilaku konsumen, dimana konsumen mempunyai keinginan dalam membeli atau memilih suatu produk, berdasarkan pengalamannya menggunakan dan mengkonsumsi suatu produk. Bila seseorang merasa senang dan puas terhadap barang atau jasa, maka hal itu akan memperkuat minat membeli, ketidakpuasan biasanya menghilangkan minat (Swastha \& Irawan, 2001). Minat beli merupakan hal yang sangat penting dalam kegiatan pemasaran, minat beli merupakan perilaku konsumen yang melandasi suatu keputusan pembelian 
yang hendak dilakukan. Dari kajian literature ditemukan bahwa salah satufaktoryangkuat mempengaruhi minat beli online adalah kualitas informasi. Menurut Li et al., (2002), informasi yang berkualitas adalah informasi yang akurat, jelas, detil, relevan, mudah didapatkan, tepat waktu, up to date dan sesuai dengan kebutuhan pengguna. Dengan kualitas informasi yang baik dan terpercaya, maka produk yang dijual oleh pelaku bisnis akan senantiasa tertanam di benak konsumen yang kemudian mendorong minat untuk membeli/mengkonsumsi produk tersebut. Sejumlah studi menemukan bahwa kualitas informasi mampu meningkatkan minat beli online secara signifikan (Rizki dkk, 2015; Rahmawati \& Nikmah, 2019; Dewi dkk, 2017; Amanusa dkk, 2015; Hatta, 2016).

Selain kualitas informasi, faktor lain yang menentukan minat beli adalah citra merek. Citra merek berperan penting dalam mendorong konsumen dalam melakukan pembelian. Citra merek merupakan ciri khas, nama, istilah, desain, atau kombinasi yang menampilkan identitas produk baik barang atau jasa, serta dapat membedakan produk itu dari produk pesaing lainnya (Kotler \& Keller, 2007:4). Citra Merek merupakan salah satu aset bagi perusahaan karena citra merek dapat membangun ketertarikan tersendiri bagi konsumen.Menggunakan jenis produk dengan merek tertentu dapat meningkatkan pengakuan diri/prestise bagi konsumen yang menggunakannya (Ambarwati \& Mukhammad, 2015). Citra merek yang positif mampu meningkatkan minat beli online secara signifikan (Ambarwati \& Mukhammad, 2015; Salfina \& Gusri, 2018; Usboko, 2018; Satria \& Sidharta, 2017; Arifin \& Fachrodji, 2015).

Berdasarkan latar belakang tersebut penulis tertarik untuk menganalisis pengaruh citra merek dan kualitas informasi terhadap minat konsumen berbelanja di Zalora.

\section{TINJAUAN PUSTAKA}

\section{Citra Merek}

Citra merek adalah jenis asosiasi yang muncul di benak konsumen ketika mengingat sebuah merek tertentu (Sopiah \& Sangadji, 2013:327). Citra Merek merupakan salah satu aset bagi perusahaan karena citra merek dapat membangun ketertarikan tersendiri bagi konsumen. Menggunakan jenis produk dengan merek tertentu dapat meningkatkan pengakuan diri/prestise bagi konsumen yang menggunakannya (Ambarwati \& Mukhamad, 2015).

Menurut Kotler dan Keller (2013:97) dimensi-dimensi utama pembentuk citra merek yaitu sebagai berikut:

1) Brand Identity (Identitas Merek) merupakan identitas fisik yang berkaitan dengan merek atau produk tersebut sehingga pelanggan mudah mengenali dan membedakannya dengan merek atau produk lain, seperti logo, warna, kemasan, lokasi, identitas perusahaan yang memayungi, slogan, dan lain-lain.

2) Brand Personality (Personalitas Merek) adalah karakter khas sebuah merek yang membentuk kepribadian tertentu sebagaimana layaknya manusia, sehingga khalayak pelanggan dengan mudah membedakannya dengan merek lain dalam kategori yang sama, misalnya karakter tegas, kaku, berwibawa, ningrat, atau murah senyum, hangat, penyayang, berjiwa sosial, atau dinamis, kreatif, independen, dan sebagainya.

3) Brand Association (Asosiasi Merek) adalah hal-hal spesifik yang pantas atau selalu dikaitkan dengan suatu merek, bisa muncul dari penawaran unik suatu produk, aktivitas yang berulang dan konsisten misalnya dalam hal sponsorship atau kegiatan 
social responsibility, isu-isu yang sangat kuat berkaitan dengan merek tersebut, ataupun person, simbol-simbol dan makna tertentu yang sangat kuat melekat pada suatu merek.

4) Brand Attitude and Behavior (sikap dan perilaku merek) adalah sikap atau perilaku komunikasi dan interaksi merek dengan pelanggan dalam menawarkan manfaat dan nilai yang dimilikinya.

5) Brand Benefit and Competence (Manfaat dan Keunggulan Merek) merupakan nilainilai dan keunggulan khas yang ditawarkan oleh suatu merek kepada pelanggan yang membuat pelanggan dapat merasakan manfaat karena kebutuhan, keinginan, mimpi, dan obsesinya terwujudkan oleh apa yang ditawarkan tersebut.

Hasil penelitian Ambarwati dan Mukhammad (2015) menemukan bahwa citra merek berpengaruh positif dan signifikan terhadap minat beli pada Mahasiswa universitas brawijaya yang menggunakan pasta gigi pepsodent. Penelitian yang dilakukan oleh Salfina dan Gusri (2018) menemukan bahwa citra merek berpengaruh positif dan signifikan terhadap minat beli pakaian anak-anak. Usboko (2018) menemukan bahwa citra merek berpengaruh signifikan terhadap minat beli Handphone Samsung (Studi Pada Universitas Sanata Dharma). Penelitian yang dilakukan Satria dan Sidharta (2017) menemukan bahwa citra merek berpengaruh positif dan signifikan terhadap minat beli konsumen Porkbal. Arifin dan Fachrodji (2015) menemukan bahwa citra merek berpengaruh signifikan terhadap minat beli konsumen Ban Achilles di Jakarta Selatan.

H1: Citra Merek berpengaruh positif dan signifikan tehadap minat beli online.

\section{Kualitas Informasi}

Kualitas informasi yaitu persepsi pelanggan terhadap suatu website mengenai kualitas informasi yang didapat (Park \& Kim, 2016). Kualitas informasi adalah kualitas yang berkaitan dengan jumlah, akurasi, dan bentuk informasi tentang produk dan jasa yang ditawarkan pada situs web. Berikut merupakan indikator-indikator kualitas informasi.

1) Akurasi: informasi yang dihasilkan oleh sistem informasi harus akurat karena sangat berperan bagi pengambilan keputusan. Informasi yang akurat berarti harus bebas dari kesalahan dan bebas dari bias.

2) Kelengkapan dari kualitas informasi adalah kelengkapan isi dari informasi yang dihasilkan oleh sistem informasi. Informasi yang lengkap adalah informasi yang mencakup seluruh informasi yang dibutuhkan oleh pengguna sistem informasi tersebut.

3) Format (Bentuk) penyajian informasi yang dihasilkan oleh sistem informasi, menggambarkan kualitas informasi sistem informasi tersebut. Jika penyajian informasi dalam bentuk yang tepat maka informasi yang dihasilkan dianggap berkualitas sehingga memudahkan pengguna untuk memahami informasi yang dihasilkan.

4) Ketepatan Waktu, kualitas informasi dari sistem informasi dapat dikatakan baik jika informasi yang dihasilkan tepat waktu,bila informasi yang dibutuhkan terlambat, maka hal ini akan berpengaruh dalam kecepatan pengambilan keputusan, dan bila pengambilan keputusan terlambat maka akan berakibat fatal terhadap pengguna maupun organisasi.

5) Relevansi, kualitas informasi suatu sistem informasi dikatakan baik bila relevan 
terhadap kebutuhan pengguna, bila informasi yang dihasilkan relevan, maka informasi tersebut akan berguna. Relevansi informasi untuk tiap-tiap pengguna berbeda satu dengan yang lain.

Penelitian Rizki dkk (2015) menemukan bahwa kualitas informasi berpengaruh positif dan signifikan terhadap minat beli dan keputusan pembelian di www.ardiansmx.com. Penelitian Rahmawati dan Nikmah (2019) menemukan bahwa kualitas informasi berpengaruh positif dan signifikan terhadap keputusan pembelian secara online di Shopee. Dewi dkk (2017) menemukan bahwa kualitas informasi berpengaruh positif terhadap minat beli konsumen pada situs jual beli Bukalapak.com. Amanusa dkk (2015), menemukan bahwa kualitas informasi berpengaruh signifikan terhadap minat dan pengguna situs jual beli online pada pengguna situs jual beli Berniaga.com. Berdasarkan penelitian Hatta (2016), kualitas informasi berpengaruh positif terhadap keputusan pembelian konsumen Samsung Galaxy Tab E-Commerce.

H2: Kualitas Informasi berpengaruh positif dan signifikan terhadap minat beli online.

\section{Minat Beli}

Kotler dan Keller (2013:36) menyatakan bahwa minat beli konsumen merupakan perilaku konsumen dimana konsumen memiliki keinginan dalam memilih, menggunakan, mengkonsumsi suatu produk yang ditawarkan. Adapun indikator minat beli menurut Ferdinand (2006) yaitu sebagai berikut:

1) Minat transaksional, yatu kecendrungan untuk membeli produk.

2) Minat referensial, yaitu kecenderungan mendorong orang lain untuk membeli produk tersebut.

3) Minat preferensial, yaitu menunjukkan perilaku yang memiliki preferensi pada produk tersebut.

4) Minat eksploratif, yaitu menunjukkan perilaku seseorang yang selalu mencari informasi mengenai produk yang diminati dan mencari informasi lain yang mendukung sifat-sifat positif dari produk tersebut.

Kerangka konseptual dalam penelitian digambarkan sebagai berikut: 
Gambar 1 Kerangka Konseptual

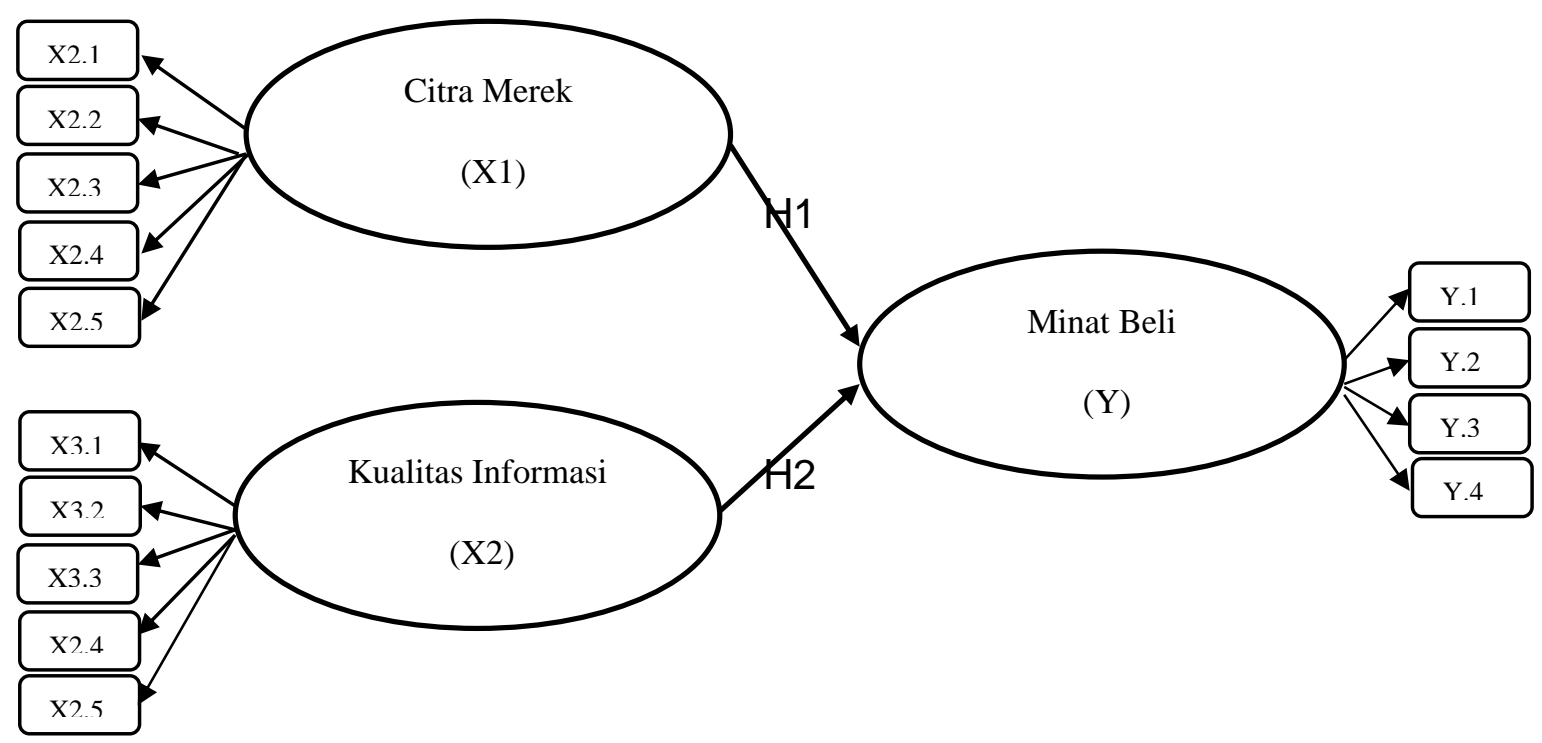

\section{METODE PENELITIAN}

Lokasi yang dipilih dalam penelitian ini adalah di Kota Denpasar. Lokasi ini dipilih karena Kota Denpasar merupakan pusat perekonomian dan kegiatan bisnis di Provinsi Bali, sehingga masyarakatnya cenderung lebih menggemari belanja online. Populasi dalam penelitian ini adalah masyarakat di Denpasar yang pernah berbelanja di situs Zalora dalam waktu 1 tahun terakhir. Menurut Sugiyono (2014:13) penelitian yang melakukan analisis dengan multivariate (korelasi atau regresi berganda), maka jumlah anggota sampel yang dianggap representative minimal 5 sampai 10 kali dari jumlah indikator yang diteliti. Penelitian ini menggunakan 14 indikator sehingga dengan menggunakan estimasi berdasarkan jumlah parameter dapat diperoleh ukuran sampel sebesar $14 \times 8=112$ responden.

Metode pengumpulan data yang digunakan dalam penelitian ini adalah metode survey dengan mengunakan kuisioner. Setiap butir pernyataan diukur dengan skala Likert, menggunakan lima angka dari 1 (sangat tidak setuju) hingga 5 (sangat setuju). Teknik analisis data yang digunakan dalam penelitian ini adalah metode analisis regresi linear berganda. Analisis regresi linear berganda digunakan untuk menaksir bagaimana pengaruh variabel bebas terhadap variabel dependen (Sugiyono, 2010:277).

\section{HASIL DAN PEMBAHASAN}

\section{Uji Validitas dan Reliabilitas}

Hasil uji validitas ditampilkan pada tabel 1 menunjukkan bahwa seluruh koefisien korelasi masing-masing indikator nilainya lebih besar dari 0,3. Hasil tersebut menunjukkan bahwa seluruh indikator dalam penelitian ini terbukti valid. 
Tabel 1

Hasil Uji Validitas

\begin{tabular}{|c|c|c|c|c|}
\hline Variabel & Kode & Item & Korelasi & Keterangan \\
\hline \multirow{5}{*}{ Citra merek } & $\mathrm{X} 1.1$ & Mengenali logo & 0,919 & Valid \\
\hline & $\mathrm{X} 1.2$ & Karakter khas & 0,887 & Valid \\
\hline & $\mathrm{X} 1.3$ & Memberikan diskon & 0,899 & Valid \\
\hline & $\mathrm{X} 1.4$ & Mencantumkan informasi & 0,890 & Valid \\
\hline & $\mathrm{X} 1.5$ & Memberikan manfaat & 0,873 & Valid \\
\hline \multirow{5}{*}{$\begin{array}{l}\text { Kualitas } \\
\text { informasi }\end{array}$} & $\mathrm{X} 2.1$ & Informasi akurat & 0,875 & Valid \\
\hline & $\mathrm{X} 2.2$ & Informasi lengkap & 0,878 & Valid \\
\hline & X2.3 & Informasi mudah dipahami & 0,833 & Valid \\
\hline & $\mathrm{X} 2.4$ & Tepat waktu & 0,850 & Valid \\
\hline & $\mathrm{X} 2.5$ & $\begin{array}{l}\text { Informasi melalui } \\
\text { email/notifikasi }\end{array}$ & 0,889 & Valid \\
\hline \multirow{4}{*}{$\begin{array}{l}\text { Minat beli } \\
\text { online }\end{array}$} & Y1 & Berbelanja kembali & 0,971 & Valid \\
\hline & Y2 & Merekomendasikan produk & 0,971 & Valid \\
\hline & Y3 & Berbelanja produk Zalora & 0,943 & Valid \\
\hline & Y4 & Mencari informasi & 0,967 & Valid \\
\hline
\end{tabular}

Hasil uji reliabilitas pada tabel 2 menunjukkan nilai Cronbach Alpha masingmasing variabel lebih besar dari 0,6 . Hal tersebut menunjukkan bahwa seluruh variabel memiliki reliabilitas yang baik.

Tabel 2

Hasil Uji Reliabilitas

\begin{tabular}{|l|c|c|}
\hline \multicolumn{1}{|c|}{ Variabel } & Cronbach's Alpha & Keterangan \\
\hline Citra merek $(\mathrm{X} 1)$ & 0,936 & Reliabel \\
\hline Kualitas informasi $(\mathrm{X} 2)$ & 0,915 & Reliabel \\
\hline Minat beli online $(\mathrm{Y})$ & 0,972 & Reliabel \\
\hline
\end{tabular}

\section{Uji Hipotesis}

Hasil analisis regresi linier berganda ditampilkan pada tabel 3. H1 diterima dengan tingkat signifikansi $0,000<0,05$, yang berarti bahwa variabel Citra merek berpengaruh positif dan signifikan terhadap Minat beli online. $\mathrm{H} 2$ diterima dengan tingkat signifikansi $0,005<0,05$, yang berarti bahwa variabel Kualitas informasi berpengaruh positif dan signifikan terhadap Minat beli online. Citra merekmemiliki nilai koefisien regresi yang lebih besar dari kualitas informasi, sehingga dapat disimpulkan bahwa Citra merek merupakan variabel yang memiliki pengaruh yang lebih dominan terhadap Minat beli konsumen berbelanja di Zalora.Nilai $\mathrm{R}^{2}$ sebesar 46,5 persen, yang berarti bahwa sebesar 46,5 persen Minat beli online konsumen berbelanja di Zalora dipengaruhi oleh variabel Citra merek (X1), Kualitas informasi (X2), dan sisanya sebesar 53,5 persen dipengaruhi oleh variabel lain yang tidak diteliti pada penelitian ini. 
Tabel 3

Hasil Uji Hipotesis

\begin{tabular}{|l|c|c|c|c|}
\hline \multirow{2}{*}{ Variabel } & \multicolumn{2}{|c|}{ Koefisien Regresi } & $\mathrm{t}$ & sig \\
\cline { 2 - 5 } & $\mathrm{B}$ & Std. Error & & \\
\hline Citra Merek & 565 & 099 & 5.689 & .000 \\
\hline Kualitas Informasi & 298 & 105 & 2.848 & .005 \\
\hline $\mathrm{R}^{2} 46,5$ & \multicolumn{5}{l}{} \\
\hline
\end{tabular}

\section{Pembahasan}

\section{Pengaruh Citra Merek Terhadap Minat Beli Online}

Meningkatnya Citra merek dapat meningkatkan Minat beli konsumen di Denpasar berbelanja di Zalora. Merek dipersepsikan positif oleh konsumen saat merek tersebut memiliki karakter yang positif, memberikan manfaat dan nilai bagi konsumen, dan dapat dengan mudah dikenali. Citra merek yang positif membentuk niat konsumen untuk mencoba dan membeli produk dengan nama merek tersebut. Hasil penelitian ini sesuai dengan penelitian yang dilakukan oleh (Ambarwati \& Mukhammad, 2015; Salfina \& Gusri, 2018; Usboko, 2018; Satria \& Sidharta, 2017; Arifin \& Fachrodji, 2015) yang menemukan bahwa Citra merek berpengaruh positif dan signifikan terhadap Minat beli online. Untuk meningkatkan Citra Merek, hal-hal yang dapat dilakukan Zalora adalah memberikan diskon secara frekuentif, menampilkan informasi produk secara detail termasuk foto dengan resolusi tinggi dan memastikan bahwa Zalora memberikan manfaat dan nilai bagi konsumen.

\section{Pengaruh Kualitas Informasi Terhadap Minat Beli Online}

Saat kualitas informasi di situs Zalora semakin baik, maka minat konsumen untuk berbelanja online di Zalora semakin meningkat. Hasil penelitian ini sesuai dengan penelitian yang dilakukan oleh (Rizki dkk, 2015; Rahmawati \& Nikmah, 2019; Dewi dkk, 2017; Amanusa dkk, 2015; Hatta, 2016) yang menemukan bahwa Kualitas informasi berpengaruh positif dan signifikan terhadap Minat beli online. Untuk meningkatkan Kualitas Informasi, hal-hal yang dapat dilakukan oleh Zalora adalah memastikan bahwa informasi produk disajikan secara akurat dan lengkap, menyajikan informasi produk dalam format yang mudah dipahami, dan mengirimkan notifikasi secara tepat waktu mengenai status pesanan.

\section{KESIMPULAN}

Saat ini aktivitas berbelanja online sangat digemari oleh masyarakat karena memberikan berbagai kemudahan. Hal ini menyebabkan banyak toko online bermunculan di Indonesia salah satunya yaitu Zalora. Zalora merupakan toko online yang diminati oleh masyarakat, dibuktikan dengan raihan top brand index tertinggi selama beberapa tahun berturut-turut. Penelitian ini bertujuan untuk menganalisis faktor-faktor yang mempengaruhi minat konsumen berbelanja di Zalora. Hasil penelitian menemukan bahwa citra merek dan kualitas informasi berpengaruh positif dan signifikan terhadap minat beli online. Dalam upaya meningkatkan minat beli online, Zalora perlu memperhatikan beberapa aspek, dalam aspek citra merek hal-hal yang perlu ditingkatkan 
oleh Zalora adalah memastikan bahwa logo Zalora mudah dikenali. Dalam aspek kualitas informasi hal-hal yang yang perlu ditingkatkan oleh Zalora adalah akurasi informasi mengenai produk, dan pengiriman notifikasi secara tepat waktu mengenai status pesanan. Keterbatasan penelitian ini adalah terbatasnya generalisasi hasil penelitian ini pada industri yang berbeda, sebab karakteristik unik dari industri dapat mengubah serangkaian faktor yang mempengaruhi minat beli konsumen. Bagi penelitian selanjutnya diharapkan dapat menganalisis variabel lain yang dapat mempengaruhi Minat beli online seperti variabel harga, kualitas produk, dan menyertakan variabel intervening seperti sikap konsumen, serta memperluas ruang lingkup penelitian yang tidak hanya terbatas pada konsumen Zalora di kota Denpasar, sehingga meningkatkan wawasan mengenai minat konsumen dalam berbelanja online.

\section{DAFTAR PUSTAKA}

Adyanto, C., \& Suryono, B.D. (2018). Pengaruh Kualitas Layanan, Brand Image, Harga Dan Kepercayaan Produk Terhadap Keputusan Pembelian Layanan E-commerce Berrybenka.com. Jurnal Manajemen Undip, Vol. 7 No. 1.

Ambarwati, M.S. \& Mukhammad, K.M. (2015). Pengaruh Citra merek terhadap minat beli pada Mahasiswa universitas brawijaya yang menggunakan pasta gigi pepsodent. Jurnal Administrasi Bisnis, Vol. 25 No. 1, pp 1-7.

Amanusa, A.K., Endang, S.A. \& Heru, S. (2015). Pengaruh kemudahan serta kualitas informasi terhadap minat dan pengguna situs jual beli online pada pengguna situs jual beli berniaga.com. Jurnal Administrasi Bisnis, Vol. 3 No. 1.

Anggraeni, P. \& Mediawati, P.N. (2016). Pengaruh Kepercayaan dan Kualitas Informasi Terhadap Keputusan Pembelian Secara Online pada Situs www.traveloka.Com. E-Proceeding of Management. Vol.3 No. 2.

Arifin, E. \& Fachrodji, A. (2015). Pengaruh Persepsi Kualitas Produk, Citra Merek, dan Promosi Terhadap Minat Beli Konsumen Ban Achilles Jakarta Selatan. Jurnal Mix, Vol. 5 No. 1, pp 124-143.

Dewi, R.Y., Yulianeu, Y., Haryono. A.T. \& Gagah, E. (2017). Pengaruh kepercayaan konsumen, kemudahan dan kualitas informasi terhadap keputusan pembelian secara online dengan minat beli sebagai variabel intervening (studi pada pengguna situs jual beli bukalapak.com). Journal of Management, Vol. 3 No.3.

Ferdinand, A. (2006). Metode Penelitian Manajemen. Semarang: Badan Penerbit Universitas Diponegoro.

Hatta, H. (2016). Pengaruh Kualitas Informasi dan Komunitas Virtual Samsung Galaxy Tab E-Commerce Terhadap Keputusan Pembelian. Jurnal Ekonomi Bisnis. Vol. 21 No. 1.

Kotler, P. \& Armstrong, G. (2003), Prinsip-Prinsip Pemasaran. Jakarta: Erlangga.

Kotler, P. \& Keller, L. (2007). Manajemen Pemasaran Edisi 12 Jilid 1. Jakarta: Indeks.

Kotler, P. \& Keller, K.L. (2013). Marketing Management. Edisi 14 Jilid Satu. England: Pearson.

Li, Y.N., Tan, K.C, \& Xie, M. (2002). Measuring Web-based Service Quality. Total Quality Management, Vol. 13, No. 5. 
Park, C.H. \& Kim, Y.G. (2003). Identifying Key Factors Affecting Consumer Purchase Behavior In An Online Shopping Context. International Journalof Retail \& Distribution Management, Vol.31, No. 1, pp.16-29.

Rahmawati, L. \& Nikmah, F. (2019). Pengaruh Kepercayaan Dan Kualitas Informasi Terhadap Keputusan Pembelian Secara Online Di Shopee. Jurnal Aplikasi Bisnis, Vol. 5 No. 1, pp 125-128.

Rizki, K.H., Endang, S.A., dan Heru, S. (2015), Pengaruh Kemudahan Dan Kualitas Informasi Terhadap Minat Dan Keputusan Pembelian Secara Online. Jurnal Manajemen Bisnis (JAB), Vol. 28 No. 1, pp 56-63.

Salfina, L. \& Gusri, H. (2018). Pengaruh Citra Merek dan Kualitas Produk Terhadap Minat Beli Produk Smartphone Merek Asus (Studi Pada Mahasiswa Fakultas Ekonomi Dan Bisnis Universitas Lampung). Jurnal Indovisi, Vol. 1 No. 1, pp 83-84.

Satria, D. \& Sidharta, H. (2017). Pengaruh Citra Merek dan Kualitas Produk Terhadap Minat Bel9i Konsumen Porkbal. Jurnal Manajemen \& Start-Up Bisnis, Vol. 2, No. 3.

Sopiah, \& Sangadji, E.M. (2016). Salesmanship. Jakarta: PT. Bumi Aksara.

Sugiyono. (2014). Metode Penelitan Kuantitatif, Kualitatif dan R\&D. Bandung: Alfabeta.

Sugiyono. (2010). Metode Penelitan Bisnis. Bandung: Alfabeta.

Swastha, B. \& Irawan. (2001). Manajemen Pemasaran Modern, Yogyakarta: Liberty Offset.

Topbrand. (2019). Top Brand Award Index Online Shop Fashion (pakaian, sepatu dan aksesoris), http://www.topbrand-award.com/top-brand-survey (diakses tanggal 15 Desember 2019).

Usboko, M.G. (2018). Pengaruh Citra Merek dan Kualitas Produk Terhadap Minat Beli Handphone Samsung. Skripsi Universitas Sanata Dharma Yogyakarta. 